\title{
Isolation and characterization of an Enterococcus- like bacterium causing muscle necrosis and mortality in Macrobrachium rosenbergii in Taiwan
}

\author{
Winton Cheng, Jiann-Chu Chen*
}

Department of Aquaculture, National Taiwan Ocean University, Keelung, Taiwan 20224, ROC

\begin{abstract}
A Cram-positive, ovoid, diplococoid bacterium tentatively identified as Enterococcus-like was isolated from diseased Macrobrachium rosenbergii in Taiwanese aquaculture ponds. The diseased prawns displayed poor growth, anorexia, inactivity, opaque and whitish musculature, and mortality. In histological preparations, melanized hemocytic granulomas were seen in the connective tissue around hemal sinuses together with hemocytic aggregation in necrotic musculature. Five isolates of diplococci were collected from diseased prawns at 4 farms and these were evaluated for 93 characteristics including morphology, physiology, biochemistry and sensitivity to antibiotics. The results indicated that the isolates belonged to a single species. They grew in 0.5 to $6.0 \% \mathrm{NaCl}$, at 10 to $40^{\circ} \mathrm{C}$, at $\mathrm{pH} 9.6$ and on bile esculin medium, gave positive pyrrolidonylarylamidase, arginine dehydrolase and Voges-Proskauer tests, were resistant to bacitracin and SXT, and were CAMP-negative and non-hemolytic on sheep blood agar. These findings indicated an Enterococcus-like bacterium closely related to Enterococcus seriolicida (recently reduced to synonymy with Lactococcus garvieaej. Experimental injection of $3 \times$ $10^{5}$ cells of strain $\mathrm{KM002}$ of this Entercoccus-like bacterium into the ventral sinus of the prawn cephalothorax caused $100 \%$ mortality in $11 \mathrm{~d}$, and induced muscular necrosis and hepatopancreatitis, gross signs and histopathology similar to those observed in the naturally infected prawns. It was concluded that this Enterococcus-like bacterium was the etiological agent associated with mortality of the farmed, diseased prawns.
\end{abstract}

KEY WORDS: Macrobrachium rosenbergii - Bacterial disease - Enterococcus · Muscle necrosis

\section{INTRODUCTION}

The giant freshwater prawn Macrobrachium rosenbergii is commercially cultured around the world and intensively so in Taiwan. Production increased from 1315 tons in 1984 to 16196 tons in 1991. However, despite a steady increase in culture area from 2316 ha in 1991 to 3185 ha in 1997, production decreased to 7612 tons ( $47 \%$ of peak production) in 1992 and 8467 tons (52\% of peak) in 1995 (New 1995, Taiwan Fisheries Bureau 1996) due to disease problems.

Prior to 1991, disease problems associated with Macrobrachium rosenbergii (Brock 1983, Liao et al. 1987. Huang 1995) included protozoal infestation (Epistylis

\footnotetext{
-Addressee for correspondence.
}

E-mail: jcchen@ntou66.ntou.edu.tw sp.) on gills and cephalothorax, fouling by filamentous algae, microsporidiosis, black spot disease, idiopathic (spontaneous) muscle necrosis and branchiostegic melanization. Recently, 2 other disease problems have been linked to production declines. These are yeast infections, mostly in the cool season (October to March), and symptoms including a yellow exoskeleton, swollen hepatopancreas, milky hemolymph and opaque and whitish muscle tissue (Shu 1993), mostly in the hot season (June to September). The latter symptoms were also associated with poor growth, anorexia and inactivity. Affected juvenile and adult prawns were first diagnosed to have Gram-positive bacterial infections in July 1994. This paper reports on diplococcal Enterococcus-like bacteria isolated from the muscle of such diseased prawns. It documents the morphological, physiological, biochemical and serological characteristics and the antibiotic sensitivity of the isolated bacte- 
ria, with comparison to reference strains of Enterococcus and Lactococcus. In addition, experimental infections to test pathogenicity were carried out with one of the isolates (KM002).

\section{MATERIALS AND METHODS}

Isolation of bacteria. Five diseased prawns showing milky musculature were collected from each of 4 farms in Pingtung county of Taiwan from July to October 1994. Bacteria were isolated from the muscle of diseased prawns from 4 different farms onto tryptic soy agar (TSA, Difco) plates incubated at $28^{\circ} \mathrm{C}$.

To isolate bacteria, the prawn cuticle was surface sterilized using $70 \%$ alcohol and then cut with a sterile scalpel to expose the underlying discolored musculature. A sterile loop was touched to the discolored tissue and then streaked onto TSA, which was then incubated at $28^{\circ} \mathrm{C}$ until visible bacterial colonies developed (approximately $24 \mathrm{~h}$ ). Single colonies of dominant types were then selected and re-streaked onto TSA to obtain pure cultures for identification tests.

Bacterial morphology and growth. Gram-stained smears from pure cultures of bacterial isolates were examined by the light microscope to determine cell size and morphology. A drop of bacterial broth was suspended in $20 \%$ sucrose solution to maintain bacterial osmolality and a drop was placed on a formvarcoated copper grid for transmission electron microscopy. After drying, the cells were negatively stained by addition of a drop of $2 \%$ phosphotungstic acid. Excess was removed by blotting and after drying the cells were observed with the transmission electron microscope. After passage of test strains in tryptic soy broth (TSB, Difco) for $24 \mathrm{~h}$ at $28^{\circ} \mathrm{C}$, motility was tested by the hanging-drop method. The ability of the strains to grow in TSB at different temperatures was tested over a period of $7 \mathrm{~d}$. Tolerance to $\mathrm{NaCl}$ was determined by the addition of $\mathrm{NaCl}$ to TSB cultures and examination for growth after $1 \mathrm{wk}$. The ability of strains to grow in TSB at pH 9.6 was also tested.

Biochemical characteristics. Test cultures were grown on TSA for $24 \mathrm{~h}$ at $28^{\circ} \mathrm{C}$, and then inoculated into test media (35 types) for biochemical tests (Facklam \& Carey 1985, Song et al. 1993). A pyrrolidonylarylamidase test kit (Oxoid) was used to determine the presence of the enzyme. Identification was based on morphological and biochemical characteristics according to standard classification manuals (Schleifer et al. 1985, Hardie 1986, Barrow \& Feltham 1993). Parallel tests were carried out with the commercial API-20 STREP system for bacteriological identification, and with the API-50 CHL system for carbohydrate fermentation (bioMerieux, France).
For antibiotic sensitivity tests, isolates were spread on TSA plates and exposed to antibiotic discs containing novobiocin $(30 \mu \mathrm{g}, \mathrm{BBL})$, chloramphenicol (30 $\mu \mathrm{g}, \mathrm{BBL})$, tetracycline $(30 \mu \mathrm{g}, \mathrm{BBL})$, kanamycin (30 $\mu \mathrm{g}, \mathrm{BBL})$, neomycin $(30 \mu \mathrm{g}, \mathrm{BBL})$, nitrofurantoin (300 $\mu \mathrm{g}, \mathrm{BBL})$, and sulfisixazale $(250 \mu \mathrm{g}, \mathrm{BBL})$. For 2, $4-$ diamino-6,7-disopropyl pteridine phosphate $(0 / 129$, $150 \mu \mathrm{g}$. Creative Microbiologicals, Taiwan) tests were done according to Seidler et al. (1980). Sensitivity to sulfamethoxazole and trimethoprim (SXT, $25 \mathrm{mg}$, Difco), bacitracin (0.04 U, Difco) and CAMP (Christie Atkins Munch-Peterson) test were carried out according to Facklam \& Carey (1985). Lancefield serotyping for groups $\mathrm{A}$ to $\mathrm{G}$ was performed using a latex streptococcal grouping Kit (Oxoid, DR 585 A).

Infectivity trials. Strain KM002 was grown on TSA for $24 \mathrm{~h}$ at $28^{\circ} \mathrm{C}$. Colonies were scraped off the plates and suspended in $0.85 \% \mathrm{NaCl}$ solution, at a concentration of $1.5 \times 10^{10} \mathrm{cfu} \mathrm{mi} \mathbf{m}^{-1}$. A series of 10 -fold dilutions of this bacterial suspension was made with $0.85 \% \mathrm{NaCl}$ solution, and $20 \mu \mathrm{l}$ of each dilution was injected into the ventral cephalothoracic sinus of 10 prawns. Prawns (10 to $15 \mathrm{~g}$ in the intermolt stage) were obtained from 2 commercial farms, and acclimated in the laboratory for 1 wk prior to experimentation. The dose of bacteria per prawn ranged from $8 \times 10^{3}$ to $3 \times 10^{8}$ cfu (see Table 5). Prawns injected with a sterile $0.85 \% \mathrm{NaCl}$ solution served as the control group. After injection, each group was held in a separate $60 \mathrm{l}$ glass aquarium containing 401 fresh water at $33.5^{\circ} \mathrm{C}$ with aeration. Prawns were fed with formulated prawn feed (Shinta Feed Company, Pingtung, Taiwan) twice a day for up to $11 \mathrm{~d}$. The number of moribund prawns was recorded daily, and bacteria were isolated from the tissues of dead prawns and characterized as described below.

Histological observation. Hepatopancreatic and muscle tissues of moribund prawns were fixed in Davidson's solution (Bell \& Lightner 1988). The fixed specimens were embedded in paraffin and cut into $5 \mu \mathrm{m}$ sections, stained with Gram stain and with modified Mayer's hematoxylin and phloxine eosin stain before viewing under the light microscope (Sheehan \& Hrachak 1980).

\section{RESULTS}

\section{Gross signs and histopathology of diseased prawns}

Prawn mortality in ponds affected in the disease outbreaks was 30 to $40 \%$. The typical signs of disease were anorexia, poor growth, inactivity and opaque and whitish musculature (Fig. 1). The opaque and whitish musculature first appeared in the cephalothorax and then extended towards the abdominal segments as 


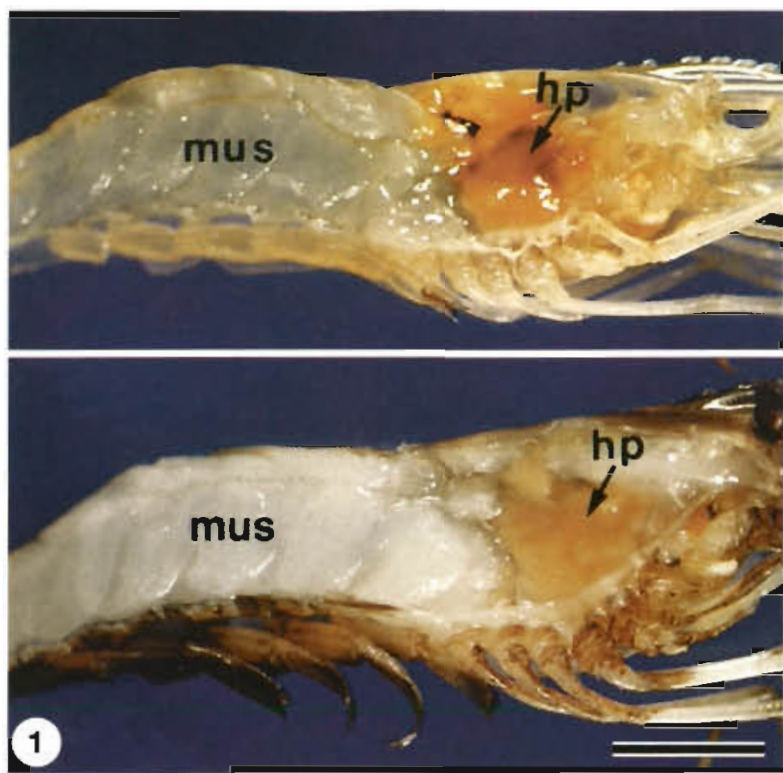

Figs. 1 to 3. Healthy and diseased Macrobrachium rosenbergii. Fig. 1. The milky musculature (mus) and yellow hepatopancreas (hp) of a farmed, infected prawn (bottom) compared to a normal prawn (top). Scale bar $=1.5 \mathrm{~cm}$ Fig. 2. Cross sections of hepatopancreatic tubules. (a) Healthy prawn. The lumen (Lum) and tubule tissues (Hpf: F-cell; Hpb: B-cell; Hpr: R-cell; Mfn: myoepithelial cell nuclei; Mef: myoepithelal layer; Brb: microvillus brush borders) and hemal sinuses (Sin) between tubules are observed. (b) Farmed, infected prawn showing necrotic tubules (small arrowhead) and melanized granuloma (large arrowhead) which is encapsulated by hemocytes and connective tissue in the region of the hemal sinus. H\&E stain, scale bar $=30 \mu \mathrm{m}$. Fig. 3 . Longitudinal sections of muscle. (a) Healthy prawn. The muscle fibers can be observed clearly. (b) Pond infected prawn showing necrotic musculature (large arrowheads) and infiltration by hemocytes (small arrowheads). Scale bar = $30 \mu \mathrm{m}$
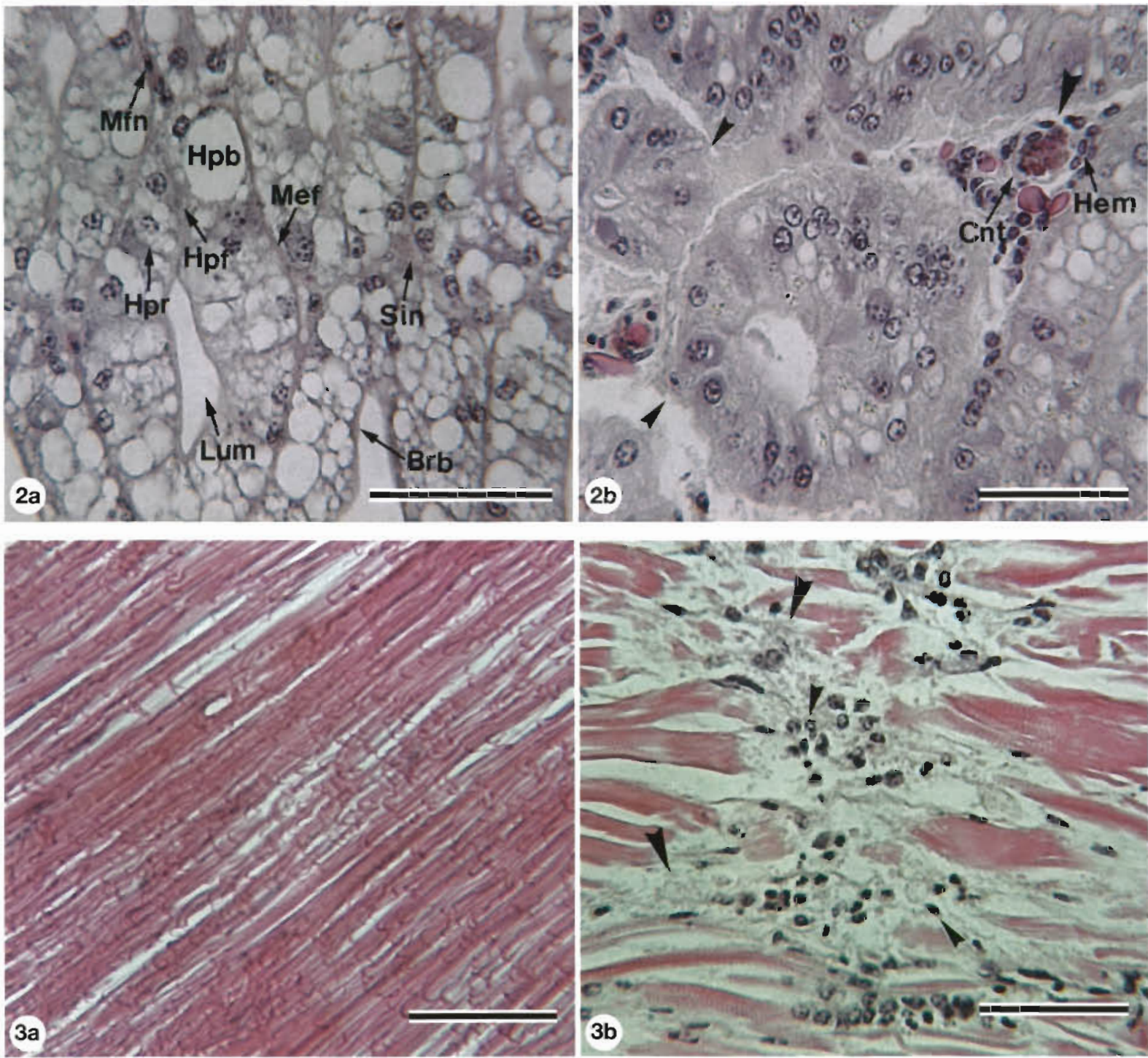
the disease advanced. Upon histological examination, large numbers of ovoid diplococci were seen to be present in the hepatopancreas and the musculature. Hepatopancreatic tubules were necrotic and aggregating hemocytes formed melanized, encapsulated granulomas in the connective tissue of the hemal sinuses (Fig. 2b). Necrotic musculature was also infiltrated with aggregating hemocytes (Fig.3b).

\section{Bacterial isolation and characterization}

Fourteen strains of bacteria were isolated from the diseased prawns. Five strains were Gram-positive diplococci; 3 were tentatively identified as Aeromonas, 3 as Staphylococcus, 2 as Pseudomonas and 1 as Citrobacter. The diplococci were the only common bacteria isolated from the diseased prawns at all the affected farms. Some physiological characteristics of these 5 strains of diplococci are given in Table 1 along with details on prawn weight and pond salinity. All the diplococcus strains were facultatively anaerobic, nonmotile, Gram-positive, ovoid diplococci (Fig. 4) that sometimes formed short chains. Endospores were not found. All strains grew in media containing 0.5 to $6.0 \% \mathrm{NaCl}$. Three out of 5 strains grew in $6.5 \% \mathrm{NaCl}$. All strains grew over a wide temperature range $\left(10\right.$ to $\left.40^{\circ} \mathrm{C}\right)$ and 3 out of 5 grew at $45^{\circ} \mathrm{C}$. The isolated strains are compared to reference strains of Enterococcus and Lactococcus in Table 2 . All strains grew in media at $\mathrm{pH} 9.6\left(28^{\circ} \mathrm{C}\right)$ and darkened bile esculin medium (Table 2).

The results of biochemical tests for the isolated and reference strains of diplococci are shown in Table 3.

Table 1. Features of the 5 strains of Enterococcus-like bacteria isolated from diseased prawns

\begin{tabular}{|c|c|c|c|c|}
\hline $\begin{array}{l}\text { Strain } \\
\text { designation }\end{array}$ & $\begin{array}{c}\text { Prawn weight } \\
\text { (g) }\end{array}$ & $\begin{array}{l}\text { Salinity } \\
\text { (ppt) }\end{array}$ & $\begin{array}{c}\mathrm{NaCl}(6.5 \%) \\
\text { tolerance }\end{array}$ & $\begin{array}{c}\text { Growth at } \\
45^{\circ} \mathrm{C}\end{array}$ \\
\hline KMO01 & $15-20$ & 0 & - & - \\
\hline KMO02 & $15-20$ & 0 & + & + \\
\hline KM003 & $15-20$ & 0 & - & + \\
\hline LMOO 1 & $10-15$ & 3 & + & + \\
\hline LM002 & $5-15$ & 4 & + & - \\
\hline
\end{tabular}

Table 2. Morphological and physiological characteristics of the Enterococcuslike strains isolated from diseased Macrobrachium rosenbergii in comparison to the reference strains of Enterococcus and Lactococcus. 3/5: 3 of 5 strains are positive; B: black; ND: not determined

\begin{tabular}{|c|c|c|c|c|}
\hline Character & $\begin{array}{l}\text { Isolated strains } \\
\qquad(\mathrm{n}=5)\end{array}$ & E. faecium ${ }^{\mathrm{a}}$ & $\begin{array}{l}\text { E. seriolicidal } \\
\text { L. garvieae }\end{array}$ & L. lactis $^{\mathrm{c}}$ \\
\hline Gram staining reaction & + & + & + & + \\
\hline Cell morphology & Ovoid & Ovoid & Ovoid & Ovoid \\
\hline Motility & - & - & - & - \\
\hline \multicolumn{5}{|l|}{$\mathrm{NaCl}$ tolerance (\%) } \\
\hline 0 & ND & ND & + & ND \\
\hline 0.5 & + & ND & ND & ND \\
\hline 1 & + & ND & ND & ND \\
\hline 2.5 & + & ND & ND & ND \\
\hline 3 & + & ND & + & ND \\
\hline 3.5 & + & ND & ND & ND \\
\hline 4 & + & ND & + & + \\
\hline 5 & + & ND & ND & ND \\
\hline 6 & + & ND & ND & ND \\
\hline 6.5 & $3 / 5$ & + & + & - \\
\hline 8 & - & ND & ND & ND \\
\hline 10 & - & ND & ND & ND \\
\hline \multicolumn{5}{|l|}{ Growth temp $\left({ }^{\circ} \mathrm{C}\right)$} \\
\hline 4 & ND & ND & + & + \\
\hline 10 & + & + & + & + \\
\hline 15 & + & ND & ND & ND \\
\hline 25 & + & ND & + & ND \\
\hline 37 & + & ND & ND & ND \\
\hline 40 & + & ND & + & - \\
\hline 45 & $3 / 5$ & + & + & - \\
\hline Growth at pH 9.6 & + & + & + & + \\
\hline \multicolumn{5}{|l|}{ Growth on: } \\
\hline Tryptic soy agar & + & + & + & + \\
\hline Bile esculin & $+B$ & + & + & + \\
\hline $\begin{array}{l}{ }^{a} \text { From Hardie (1986), B } \\
{ }^{b} \text { From Schleifer et al. (1 } \\
\text { cFrom Schleifer et al. (1 }\end{array}$ & $\begin{array}{l}\text { Barrow \& Felth } \\
\text { (1985), Toranzo } \\
\text { (1985), Hardie ( }\end{array}$ & $\begin{array}{l}\text { (1993) } \\
\text { et al. (1994) } \\
\text { 1986), Barrow }\end{array}$ & \& Feltham (1 & \\
\hline
\end{tabular}

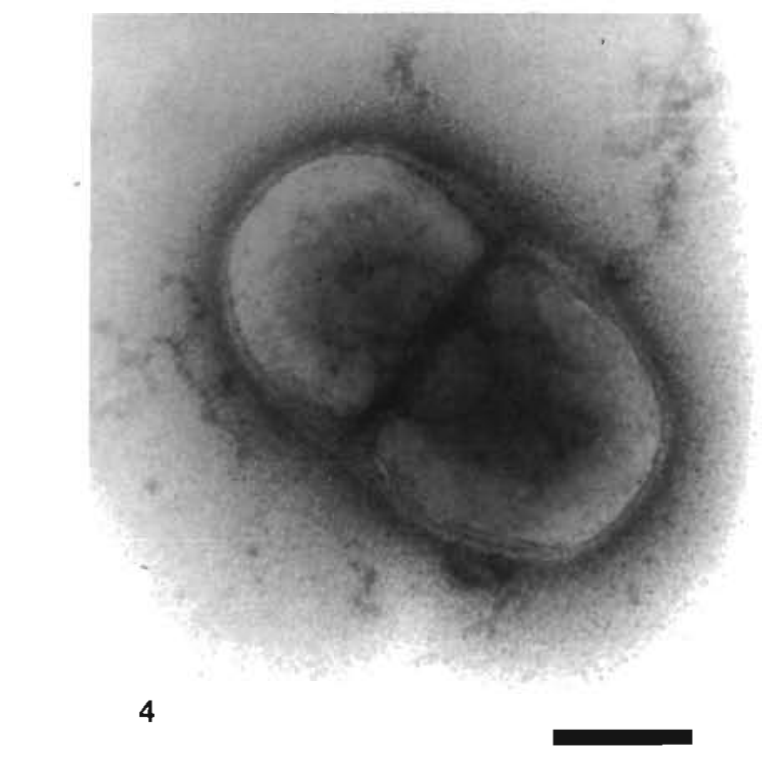

Fig. 4. Electron micrograph of Enterococcus-like strain KM002 showing dividing cells (negative staining with $2 \%$ phosphotungstic acid). Scale bar $=0.4 \mu \mathrm{m}$ 

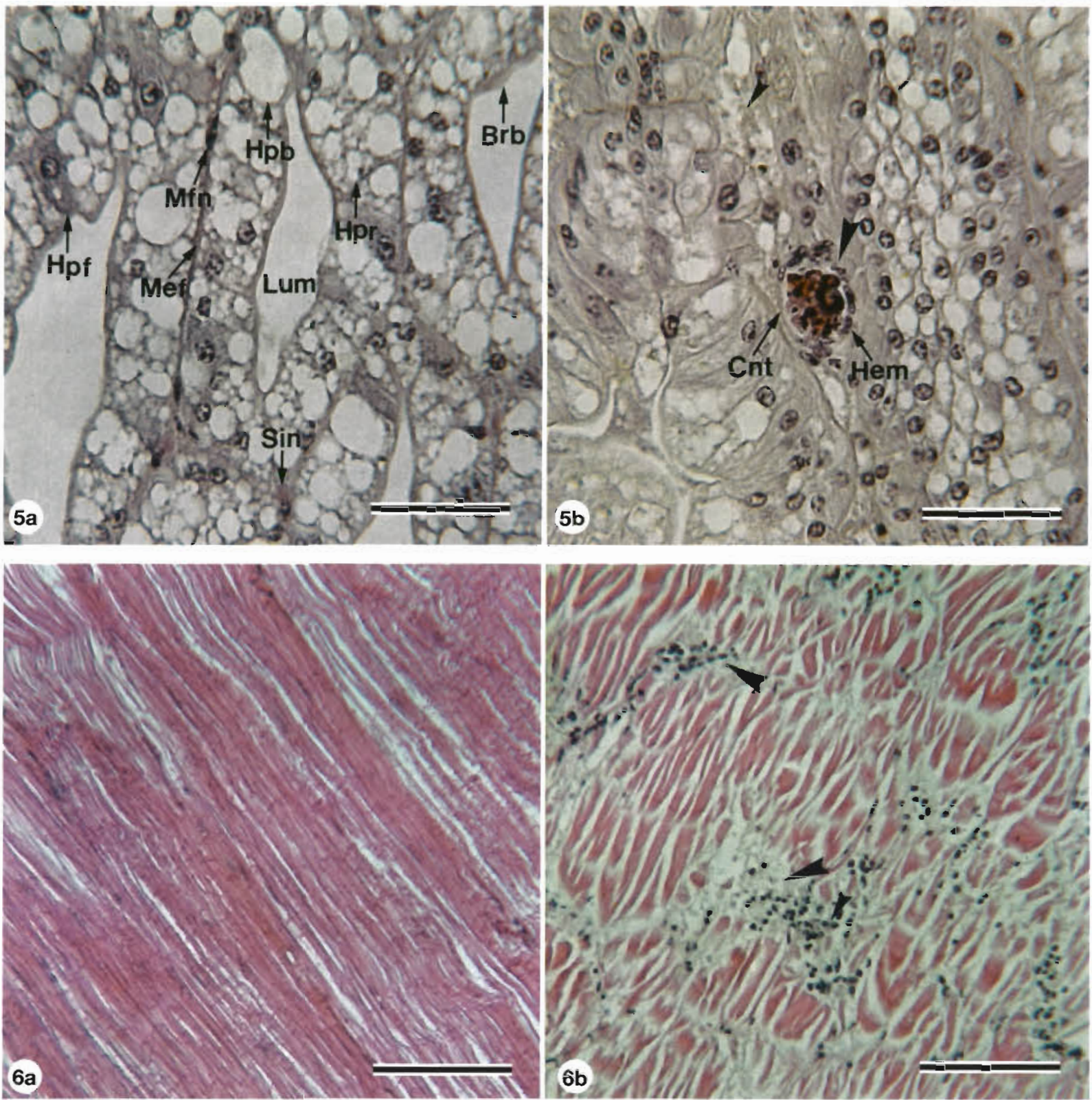

Figs. $5 \& 6$. Healthy and experimentally infected Macrobrachium rosenbergii. Fig. 5. Cross sections of hepatopancreatic tubules of prawns from the infection test. (a) Control prawn showing normal lumens (Lum), tubule tissues (Hpf: F-cell; Hpb: B-cell; Hpr: R-cell; Mfn: myoepithelial cell nuclei; Mef: myoepithelial layer; Brb: microvillus brush borders) and hemal sinuses (Sin) between tubules. (b) Experimentally infected prawn showing necrotic tubules (small arrowhead) and a melanized granuloma (large arrowhead) which is encapsulated by hemocytes and connective tissue in the region of the hemal sinus. H\&E stain, scale bar $=30 \mu \mathrm{m}$. Fig. 6. Longitudinal sections of muscle tissue of prawns from the infection test. (a) Healthy prawn tissue showing normal muscle fibres. (b) Experimentally infected prawn tissue showing necrotic musculature (large arrowhead) infiltrated by hemocytes (small arrowhead). H\&E stain, scale bar $=60 \mu \mathrm{m}$

All strains gave positive reactions for arginine dehydrolase, leucine arylamidase and pyrrolidonylarylamidase, but negative reactions for oxidase, catalase, $\alpha$-galatosidase, $\beta$-glucuronidase, $\beta$-galactosidase, tyrosinase, alkaline phosphatase, ornithine and lysine decarboxylase and trytophanase. None were capable of utilizing citrate as the sole carbon source and none could reduce nitrate to nitrite under anaerobic conditions. All strains hydrolyzed hippurate and esculine, but not gelatin, casein, starch or chitin. Hydrogen sulfide was not produced. Hemolytic activities for sheep RBC (red blood cells) and CAMP were not observed. All strains were negative for rhamnose, galactose and lactose assimilation with the API system. However, 1 of 
the 5 and 3 of the 5 were positive for rhamnose and lactose assimilation, respectively, and all were positive for galactose assimilation by conventional test methods (Table 3 ).

All isolated strains were sensitive to $0 / 129$, novobiocin, chloramphenicol, kanamycin, neomycin and nitrofurantoin. However, they were resistant to tetracycline, sulfisoxazole, bacitracin and SXT (Table 4). None of the isolated strains responded to Lancefield A, B, C, $D, E$ and $G$ group antisera (Table 3 ).

The characteristics of the isolated diplococci indicated that they belonged to the genus Enterococcus. All strains grew at 10 and $40^{\circ} \mathrm{C}$, in $6 \%$ $\mathrm{NaCl}$ and at $\mathrm{pH}$ 9.6. The overall phenotypic tests in Table 3 indicated that the isolated strains had a high level of similarity to Enterococcus seriolicida, which has recently been reduced to synonymy with Lactococcus garvieae (Eldar et al. 1996).

\section{Experimental infections}

Prawns injected with isolated strain KM002 by injection into the ventral sinus of the cephalothorax developed opaque and whitish musculature, and eventually died. A bacterial dose of $3 \times$ $10^{5} \mathrm{cfu}$ induced $100 \%$ mortality in $11 \mathrm{~d}$ at $33.5^{\circ} \mathrm{C}$ (Table 5). Prawn mortality occurred earlier when the dosage of bacteria was increased. A dose of $8 \times 10^{3} \mathrm{cfu}$ caused $10 \%$ mortality, with similar gross signs and histopathology in the moribund prawns. From Day 4 after injection, prawns developed opaque and whitish musculature, which expanded from the cephalothorax towards the abdominal segments. The infected prawns displayed necrotic hepatopancreatic tubules, melanized granulomas in the connective tissue of the hemal sinuses (Fig. 5b), and necrotic musculature infiltrated by hemocytes (Fig. 6b). Survival in the control group was $100 \%$ and hepatopancreatic and muscle tissues were normal (Figs. 5a \& 6a). Re-isolation of the injected bacteria from the moribund prawns confirmed Koch's postulates.
Table 3. Biochemical characteristics of the isolated strains from diseased Macrobrachium rosenbergii in comparison to the reference strains of the Enterococcus and Lactococcus group. 1/5: 1 of 5 strains positive; ND: not determined; $\mathrm{d}: 11$ to $80 \%$ of strains positive; \pm : reactions showing discrepancy in the results depending on the method used (conventional tests versus API system)

\begin{tabular}{|c|c|c|c|c|}
\hline Character & $\begin{array}{l}\text { ted strains } \\
(n=5)\end{array}$ & E. faecium ${ }^{a}$ & $\begin{array}{l}\text { E. seriolicidal } \\
\text { L. garvieae }\end{array}$ & L. lactis ${ }^{\circ}$ \\
\hline Catalase production & - & - & - & - \\
\hline Oxidase production & - & - & - & - \\
\hline Haemolysis (SRBC) & - & - & - & - \\
\hline CAMP & - & ND & ND & ND \\
\hline $\mathrm{O} / \mathrm{F}$ reaction & $-1-$ & ND & $\mathrm{F}$ & $\mathrm{F}$ \\
\hline Citrate utilization & - & ND & ND & ND \\
\hline Acetoin production & + & + & + & + \\
\hline $\mathrm{H}_{2} \mathrm{~S}$ production & - & - & - & - \\
\hline Indole production & - & ND & - & ND \\
\hline $\mathrm{NO}_{3}$ reduction & - & ND & ND & ND \\
\hline \multicolumn{5}{|l|}{ Hydrolysis of: } \\
\hline Gelatin & - & - & - & ND \\
\hline Casein & - & - & - & ND \\
\hline Starch & - & - & - & - \\
\hline Chitin & - & ND & ND & ND \\
\hline Hippurate & + & $d$ & $\mathrm{~d}$ & $\mathrm{~d}$ \\
\hline Tyrosine decomposition & - & - & ND & - \\
\hline Esculin & + & + & + & + \\
\hline \multicolumn{5}{|l|}{ Decarboxylation of: } \\
\hline Lysine & - & ND & - & ND \\
\hline Arginine & + & + & + & + \\
\hline Ornithine & - & - & - & - \\
\hline Pyrrolidonylarylamidase & + & + & + & $\mathrm{d}$ \\
\hline$\alpha-$ Galactosidase & - & ND & - & - \\
\hline$\beta$-Glucuronidase & - & ND & $d$ & - \\
\hline$\beta$-Galactosidase & - & ND & - & - \\
\hline Alkaline phosphatase & - & - & - & - \\
\hline Leucine arylamidase & + & + & + & + \\
\hline \multicolumn{5}{|l|}{ Acid production from: } \\
\hline Glycerol & - & + & - & - \\
\hline Erythritol & - & ND & - & - \\
\hline D-Arabinose & - & + & - & d \\
\hline L-Arabinose & - & + & - & $\mathrm{d}$ \\
\hline Ribose & + & + & + & + \\
\hline D-Xylose & + & ND & - & $d$ \\
\hline L-Xylose & - & ND & - & $\mathrm{d}$ \\
\hline Adonitol & - & - & - & - \\
\hline$\beta$-Methyl-D xyloside & - & ND & - & - \\
\hline Galactose & + & ND & + & + \\
\hline Glucose & + & ND & + & + \\
\hline Fructose & + & ND & + & + \\
\hline Mannose & + & ND & + & + \\
\hline Sorbose & - & ND & - & - \\
\hline Rhamnose & $1 / 5$ & ND & - & - \\
\hline Dulcitol & - & ND & - & - \\
\hline Inositol & - & ND & - & - \\
\hline Mannitol & + & + & + & $\mathrm{d}$ \\
\hline Sorbitol & - & $\mathrm{d}$ & \pm & - \\
\hline$\alpha$-Methyl-D mannoside & - & ND & - & - \\
\hline$\alpha$-Methyl-D glucoside & - & ND & - & - \\
\hline N Acetyl glucosamine & + & ND & + & + \\
\hline Anygdalin & + & ND & + & d \\
\hline Arbutin & + & + & + & $d$ \\
\hline Salicin & + & ND & + & + \\
\hline Cellobiose & + & ND & + & + \\
\hline Maltose & + & $\mathrm{ND}$ & + & + \\
\hline Lactose & $3 / 5$ & + & \pm & $d$ \\
\hline Melibiose & - & + & - & - \\
\hline Sucrose & + & + & d & d \\
\hline
\end{tabular}


Table 3 (continued)

\begin{tabular}{|c|c|c|c|c|}
\hline Character & $\begin{array}{l}\text { Isolated strains } \\
\qquad(\mathrm{n}=5)\end{array}$ & E. faecium ${ }^{a}$ & $\begin{array}{l}\text { E. seriolicida' } \\
\text { L. garvieae }\end{array}$ & L. Iactis ${ }^{\mathrm{C}}$ \\
\hline Trehalose & + & + & + & $d$ \\
\hline Inulin & + & $d$ & - & - \\
\hline Melezitose & - & - & - & - \\
\hline Raffinose & - & d & - & - \\
\hline Starch & + & $\mathrm{d}$ & - & + \\
\hline Glycogen & - & ND & - & - \\
\hline Xylitol & - & ND & - & - \\
\hline Gentibiose & + & ND & + & + \\
\hline D Turanose & - & ND & - & - \\
\hline D Lyxose & - & ND & - & - \\
\hline D Tagatose & - & ND & $d$ & - \\
\hline D Fucose & - & ND & - & - \\
\hline I Fucose & - & ND & - & - \\
\hline D Arabitol & - & ND & - & - \\
\hline L Arabitol & - & ND & - & - \\
\hline Gluconate & + & ND & d & - \\
\hline 2 Keto gluconate & - & ND & - & - \\
\hline 5 Keto gluconate & - & ND & - & - \\
\hline Lancefield group type & - & $\mathrm{D}$ & - & - \\
\hline \multicolumn{5}{|c|}{$\begin{array}{l}\text { a From Hardie (1986), Barrow \& Feltham (1993) } \\
\text { bFrom Schleifer et al. (1985), Toranzo et al. (1994) }\end{array}$} \\
\hline
\end{tabular}

Brock (1983) reported diffuse muscle opacity and softening of the exoskeleton in white syndrome in Macrobrachium rosenbergï, which displays gross signs similar to the white muscle disease described here. However, the microscopic pathology described by Brock (1983) was different. In addition, he isolated several bacterial species, including $\alpha$ Streptococcus, from the hemolymph of the infected prawns and suggested that the disease had a nutritional or environmentally related etiology. The lack of detailed characterization of the isolated bacteria makes comparisons difficult, so these diseases may or may not be different.

The first description of streptococci as an etiological agent of fish disease was by Hoshina et al. (1958). Since then, epizootics of streptococcal septicemia have been reported only sporadically among cultured and wild populations of freshwater and marine fish (Kitano 1993). Streptococcosis

\section{DISCUSSION}

Handling, crowding and several environmental factors such as salinity, temperature and low dissolved oxygen can cause opaque and whitish musculature of decapod crustaceans. This is commonly known as muscle necrosis or spontaneous necrosis (Lakshmi et al. 1978, Brock 1983, Lightner 1983). This opaque and whitish musculature commences at the tail, and progresses to the head, which then turns to red (Lightner 1983). No bacterial cells are present. These changes are reversible during the initial stages of development, if the causative stressor is eliminated. Huang (1995) has observed spontaneous necrosis in Macrobrachium rosenbergii, which is characterized by a hyaline degeneration of the musculature, followed by necrosis with no hemocytic infiltration and no bacteria present. These observations contrast with the observations for the infected prawns in the present study. Here, the opaque and whitish musculature developed first in the cephalothorax and then progressed towards the abdomen and it was accompanied by necrosis and gross infiltration of hemocytes in the muscles and the hepatopancreas, where Gram-positive bacteria could be found. caused by Enterococcus-like bacteria has been observed in turbot Scophthalalmus maximus (Toranzo et al. 1994), and in Oncorhynchus mykiss (Ceschia et al. 1992, Ghittino \& Prearo 1992, Palacios et al. 1993). Enterococcus seriolicida was reported to be associated with mortalities in yellowtail Seriola quinqueradiata by Kusuda et al. (1991). It had previously been isolated and classified as Streptococcus (Kusuda et al. 1976). Although E. seriolicida is known as a pathogen of saltwater fish species (except for eels), it has never been

Table 4. Sensitivities to antibiotic disks for the strains isolated from diseased Macrobrachium rosenbergii in comparison to the reference strains of the Enterococcus and Lactococcus group. SXT: sulfamethoxazole and trimethoprim; ND: not determined

\begin{tabular}{|c|c|c|c|c|}
\hline Character & $\begin{array}{c}\text { rawn isolates } \\
(n=5)\end{array}$ & E. faecium ${ }^{a}$ & $\begin{array}{l}\text { E. seriolicida/ } \\
\text { L. garvieae }\end{array}$ & E. lactis ${ }^{\mathrm{c}}$ \\
\hline $0 / 129(150 \mu \mathrm{g})$ & ND & ND & ND & ND \\
\hline Novobiocin $(30 \mu \mathrm{g})$ & $\mathrm{S}$ & ND & ND & ND \\
\hline Chloramphenicol $(30 \mu \mathrm{g})$ & g) & ND & $\mathrm{S}$ & ND \\
\hline Tetracycline $(30 \mu g)$ & $\mathrm{R}$ & ND & $\mathrm{S}$ & ND \\
\hline Kanamycin $(30 \mu \mathrm{g})$ & $\mathrm{S}$ & ND & ND & ND \\
\hline Neomycin $(30 \mu \mathrm{g})$ & $\mathrm{S}$ & ND & ND & ND \\
\hline Nitrofurantoin $(300 \mu \mathrm{g})$ & $\mathrm{S}$ & ND & $\mathrm{S}$ & ND \\
\hline Sulfisixazole $(250 \mu \mathrm{g})$ & $\mathrm{R}$ & ND & ND & ND \\
\hline Bacitracin & $\mathrm{R}$ & ND & ND & ND \\
\hline $\mathrm{SXT}$ & $\mathrm{R}$ & ND & ND & ND \\
\hline $\begin{array}{l}\text { a From Hardie (1986), Ba } \\
{ }^{b} \text { From Schleifer et al. (19 } \\
{ }^{\circ} \text { From Schleifer et al. (19 }\end{array}$ & $\begin{array}{l}\text { Barrow \& Felth } \\
\text { 1985), Toranzo } \\
\text { 1985), Hardie ( }\end{array}$ & $\begin{array}{l}\text { am (1993) } \\
\text { et al. (1994) } \\
(1986), \text { Barrov }\end{array}$ & $v \&$ Feltham $(1$ & \\
\hline
\end{tabular}


Table 5. Experimental infection of Macrobrachium rosenbergi (body weight 10 to $15 \mathrm{~g}$ ) injected with isolated strain (KM002). Data are no. of prawns (out of 10 at each dilution) that died over a period of $11 \mathrm{~d}$ at $33.5^{\circ} \mathrm{C}$

\begin{tabular}{|c|c|c|c|c|c|c|c|c|c|c|c|}
\hline $\begin{array}{l}\text { Route of } \\
\text { infection }\end{array}$ & $\begin{array}{l}\text { Bacterial dose } \\
\text { (cfu prawn }{ }^{-1} \text { ) }\end{array}$ & 3 & 4 & $\begin{array}{c}\text { Tin } \\
5\end{array}$ & $\begin{array}{r}1 e \\
6\end{array}$ & $\operatorname{lar}_{7}$ & $\begin{array}{c}\sec \\
8\end{array}$ & $\begin{array}{l}\text { (d) } \\
9\end{array}$ & 10 & 11 & $\begin{array}{l}\text { Cumulative } \\
\text { mortality (\%) }\end{array}$ \\
\hline $\begin{array}{l}\text { Injection into } \\
\text { ventral sinus of } \\
\text { cephalothorax }\end{array}$ & $\begin{array}{l}3 \times 10^{8} \\
3 \times 10^{7} \\
3 \times 10^{6} \\
3 \times 10^{5} \\
8 \times 10^{4} \\
8 \times 10^{3} \\
\text { Saline }\end{array}$ & & 1 & $\begin{array}{l}3 \\
1 \\
1\end{array}$ & $\begin{array}{l}3 \\
2 \\
1 \\
1\end{array}$ & $\begin{array}{l}2 \\
1 \\
1 \\
3 \\
1 \\
1\end{array}$ & $\begin{array}{l}1 \\
2 \\
4 \\
2 \\
1\end{array}$ & $\begin{array}{l}2 \\
3 \\
1\end{array}$ & 2 & 1 & $\begin{array}{r}100 \\
100 \\
100 \\
100 \\
20 \\
10 \\
0\end{array}$ \\
\hline
\end{tabular}

due to the accumulation of feces, unconsumed feed, carcass debris and molted shells. These wastes may constitute a favorable environment for the growth of Enterococcus-like bacteria and may also reduce prawn immunocompetence. High organic loads and poor water quality have been reported to contribute to an increase in numbers of bacteria in rearing ponds (Cook \& Lofton 1973, Sindermann 1974, Ueda et al. 1992). There is also a direct relationship between bacterial concentration in water and bacterial

described in freshwater species. Nor has it been described outside Japan.

Using the API system, the strains were identified as Lactococcus lactis. Murray (1990) reported that $56 \%$ of lactococci tested grew in $6.5 \% \mathrm{NaCl}$ and that $25 \%$ of these, in turn, grew at $\mathrm{pH} 9.6$. However, in tests using the API 20 STREP and $\mathrm{CH} 50$ systems, Eldar et al. (1996) found no difference between Italian field isolates and reference strains of Enterococcus seriolicida and $L$. garvieae. They reported strain variability for growth at $6.5 \% \mathrm{NaCl}$ and at $\mathrm{pH} 9.6$ or at $45^{\circ} \mathrm{C}$, and identified these strains with a probability of $79.8 \%$ as Lactococcus lactis. Using genotypic methods, Eldar et al. (1996) obtained results in favor of the argument that E. seriolicida is a synonym of $L$. garvieae.

On the other hand, tests for hemolysis and CAMP, for susceptibility to bacitracin and SXT, for hydrolysis of PYR (L-pyrrolidonyl- $\beta$-naphthylamine) and hippurate, for salt-tolerance $(6.5 \% \mathrm{NaCl})$, for heat-tolerance $\left(45^{\circ} \mathrm{C}\right)$, for growth in bile esculin and for growth at $\mathrm{pH}$ 9.6 are important criteria for differentiation of streptococci (Facklam \& Carey 1985, Schleifer \& Kilpper-Balz 1987). Enterococci are generally more salt-tolerant and heat-resistant than other streptococci (Barrow \& Feltham 1993). They are also resistant to bacitracin and SXT, positive for pyrrolidonylarylamidase, negative for CAMP and positive for growth at $10^{\circ} \mathrm{C}$ and on bile esculin (Facklam \& Carey 1985, Schleifer \& KilpperBalz 1987). According to our findings, the strains isolated from the diseased prawns would be classified in the genus Enterococcus. Further research on genotypic, molecular and antigenic characteristics for the Enterococcus-like bacterium isolated from diseased, farmed Macrobrachium rosenbergii is needed

Enterococcal muscle necrosis of Macrobrachium rosenbergii commonly occurs during the summer when there are phytoplankton blooms. Prawn farmers have experience which suggests that exchanging ground water at this time may decrease prawn mortality, if it is implemented when disease signs first begin to appear. They consider that infections occur concentration in hemolymph (Brady \& Lasso de la Vega 1992). There are also reports to indicate that adverse environmental conditions can have a negative effect on measured defense parameters and resistance to illness (Dean \& Vernberg 1966, Truscott \& White 1990). Further research is needed to study the susceptibility of $M$. rosenbergii to this Enterococcus-like bacterium under different environmental conditions.

Acknowledgements. The authors thank the National Science Council for a research scholarship to $\mathrm{W}$. Cheng and Mr C. S. Kuo for his assistance in prawn culture.

\section{LITERATURE CITED}

Barrow GI, Feltham RK (1993) Cowan and Steel's manual for the identification of medical bacteria. Cambridge University, Cambridge

Bell TA, Lightner DV (1988) A handbook of normal penaeid shrimp histology. World Aquaculture Society, Baton Rouge, LA

Brady YJ, Lasso de la Vega E (1992) Recovery of Serratia marcescens in haemolymph of Macrobrachium rosenbergii from experimentally seeded water. J World Aquacult Soc 23:228-231

Brock JA (1983) Diseases (infectious and noninfectious), metazoan parasites, predators, and public health considerations in Macrobrachium culture and fisheries. In: McVey JP (ed) CRC handbook of mariculture, Vol 1, Crustacean aquaculture. CRC Press, Boca Raton, Fl, p 329-370

Ceschia G, Giorgetti G, Giavenni R, Sarti M (1992) A new problem for Italian trout farms: Streptococcosis in rainbow trout (Oncorhynchus mykiss). Bull Eur Assoc Fish Pathol $12: 71-72$

Cook DW, Lofton SR (1973) Chitinoclastic bacteria associated with shell disease in Penaeus shrimp and the blue crab (Callinectes sapidus). J World Dis 9:154-159

Dean JM, Vernberg FJ (1966) Hypothermia and the blood of crabs. Comp Biochem Physiol 17B:19-22

Eldar A, Ghittino C, Asanta L, Bvozzetta E, Goria M (1996) Enterococcus serioloicida is a junior synonym of Lactococcus garvieae, a causative agent of septicemia and meningoencephaliyis in fish. Current Microbiol 32:85-88

Facklam RR, Carey RB (1985) Manual of clinical microbiology, 4th edn. In: Lennette EH, Ballows A, Hausler WJ Jr, Shadomy HJ (eds) Streptococci and Aerococci. American 
Society for Microbiology, Washington, DC, p 154-175

Ghittino C, Prearo M (1992) Segnalazione di Streptococcosi nella trota iridea (Oncorhynchus mykiss) in Italia: nota preliminare. Boll Soc Ital Patol 8:4-11

Hardie JM (1986) Genus Streptococcus Rosenbach (1884). In Sneath PHA, Mair NS, Sharpe ME, Holt JG (eds) Bergey's manual of systematic bacteriology, Vol 2. Williams and Wilkens, Baltimore, p 1043-1071

Hoshina T, Sano T, Morimoto Y (1958) A Streptococcus pathogenic to fish. J Tokyo Univ Fish 44:57-68

Huang SH (1995) Special issue on disease prevention of Macrobrachium rosenbergii. Pingtung Hsiang Livestock Disease Control Center, Pingtung, Taiwan

Kitano T (1993) Streptococcal infection. In: Inglis V, Roberts RJ, Bromage NR (eds) Bacterial disease of fish. Blackwell, Oxford

Kusuda R, Kawai K, Salati F, Banner CR, Fryer JL (1991) Enterococcus seriolicida sp. nov., a fish pathogen. Int $\mathrm{J}$ Syst Bacteriol 41:406-409

Kusuda R, Kawai K, Toyoshima T, Komatsu I (1976) A new pathogenic bacterium belonging to the genus Streptococcus isolated from an epizootic of cultured yellowtail. Bull Jpn Soc Sci Fish 42:1345-1352

Lakshmi GJ, Venkataramiah A, Howse HD (1978) Effect of salinity and temperature changes on spontaneous muscle necrosis in Penaeus aztecus. Aquaculture 13:35-43

Liao IC, Yang ER, Lau SW (1987) Preliminary report on some diseases of cultured prawn and their control methods Coastal Fish Ser (Taiwan) 12:161-166

Lightner DV (1983) Diseases of culture penaeid shrimp. In McVey JP (ed) CRC handbook of mariculture, Vol 1, Crustacean aquaculture. CRC Press, Boca Raton, FL p 289-320

Murray BB (1990) The life and times of the Enterococcus. Clin Microbiol Rev 3:46-65

New MB (1995) Status of freshwater prawn farming: a review Aquacult Res 26:1-54

Palacios MA, Zamora MJ, Velazquez J, Zamora E, Duran A

Editorial responsibility: Timothy Flegel,

Bangkok, Thailand
(1993) Streptococcosis in rainbow trout (Oncorhynchus mykiss) in Spain. Boll Sci Ital Patol 13:11-14

Schleifer KH, Kilpper-Balz R (1987) Molecular and chemotaxonomic approaches to the classification of streptococci, enterococci and lactocci: a review system. Appl Microbiol $10: 1-9$

Schleifer KH, Kraus J, Dvorak C, Klipper-Balz R, Collins MD, Fischer W (1985) Transfer of Streptococcus lactis and related Streptococci to the genus Lactococcus gen. nov. syt. Appl Microbiol 6:184-195

Sheehan DC, Hrachak BB (1980) Theory and practice of histotechnology, 2nd edn. The C. V. Mosby Co., St. Louis, MO

Sindermann CJ (1974) Diagnosis and control of mariculture disease in the United States. US Dept Commerce Tech Series 2:27-31

Shu JP (1993) Studies on yeast infection in cultured giant freshwater prawn (Macrobrachium rosenbergii). MS thesis, Dept Veterinary, Chung-Hsing University, Taiwan

Song YL, Cheng W, Wang CH (1993) Isolation and characterization of Vibrio damsela infectious for cultured shrimp in Taiwan. J Invertebrate Pathol 61:24-31

Taiwan Fisheries Bureau (1996) Fisheries Yearbook Taiwan Area 1994. Taipei, Taiwan

Toranzo AE, Devesa S, Heinen P, Riaza A, Nunez S, Barja JL (1994) Streptococcosis in cultured turbot caused by an Enterococcus-like bacterium. Bull Eur Assoc Fish Pathol $14: 19-23$

Truscott R, White KN (1990) The influence of metal and temperature stress on the immune system of crabs. Funct Ecol $4: 455-461$

Ueda R, Sugita H, Deguchi Y (1992) Microflora associated with the developing giant prawn, Macrobrachium rosenbergii. In: Chou LM, Munro AD, Lam TJ, Chen TW, Cheong LKK, Ding JK, Hooi KK, Khoo HW, Phang VPE, Shim KF, Tan CH (eds) The abstract of third Asian Fisheries Forum. The Asian Fisheries Society, Manila, Philippines, p 209

Submitted: August 13, 1997; Accepted: May 25, 1998 Proofs received from author(s): September 9, 1998 